\title{
Astyanax aff. fasciatus Cuvier, 1819 (Teleostei; Characidae): evidences of a species complex in the upper rio Tibagi basin (Paraná, Brazil)
}

\author{
Roberto Ferreira Artoni*, Oscar Akio Shibatta**, Maria Claudia Gross*, \\ Carlos Henrique Schneider*, Mara Cristina de Almeida*, \\ Marcelo Ricardo Vicari*** and Luiz Antonio Carlos Bertollo***
}

Four populations of Astyanax aff. fasciatus of the upper rio Tibagi (municipal district of Ponta Grossa, Paraná State, Brazil), had their karyotypes and morphometry analyzed. The cytogenetic data show the occurrence of distinct karyotypes (cytotypes), here named cytotype A, with $2 \mathrm{n}=48$ chromosomes $(6 \mathrm{~m}+18 \mathrm{sm}+14 \mathrm{st}+10 \mathrm{a})$, cytotype $\mathrm{B}$, with $2 \mathrm{n}=50$ chromosomes $(8 m+18 s m+14 s t+10 a)$ and cytotype $C$, with $2 n=50$ chromosomes $(8 m+18 s m+14 s t+10 a)$. The distribution pattern of the constitutive heterochromatin was very similar between cytotypes A and B, but diverged in relation to cytotype $\mathrm{C}$. Distinct cytotypes may occur in sympatry in the upper rio Tibagi region, with the exception of the Furna 2 sample, which presents cytotype A exclusively. In addition, a specimen with $2 \mathrm{n}=49$ chromosomes $(7 \mathrm{~m}+18 \mathrm{sm}+14 \mathrm{st}+10 \mathrm{a})$ was also found and, by the characteristics presented, may be a consequence of a rare hybridization event between cytotypes A and B. The morphometric analyses of canonical variates indicate a consistent isolation of the Furna 2 sample, while the other samples seem to be superimposed, indicating a possible gene flow or even a recent isolation event. This model points to a probable complex of cryptic species in the studied region.

Quatro populações de Astyanax aff. fasciatus do alto rio Tibagi (município de Ponta Grossa, Paraná, Brasil) foram citogeneticamente e morfometricamente analisadas. Os dados citogenéticos mostram a ocorrência de distintos cariótipos (citótipos), aqui nomeados citótipo $\mathrm{A}, \operatorname{com} 2 \mathrm{n}=48(6 \mathrm{~m}+18 \mathrm{sm}+14 \mathrm{st}+10 \mathrm{a})$, citótipo $\mathrm{B}$, com $2 \mathrm{n}=50(8 \mathrm{~m}+18 \mathrm{sm}+14 \mathrm{st}+10 \mathrm{a})$ e citótipo $\mathrm{C}, \operatorname{com} 2 \mathrm{n}=50$ cromossomos $(8 \mathrm{~m}+18 \mathrm{sm}+14 \mathrm{st}+10 \mathrm{a})$. O padrão de distribuição da heterocromatina constitutiva foi muito similar entre os citótipos A e B, mas mostrou-se divergente em relação ao citótipo C. Citótipos distintos podem ocorrer em simpatria na região do alto rio Tibagi, com exceção da amostra da Furna 2, a qual apresenta somente o citótipo A exclusivamente. Além disso, um exemplar com $2 \mathrm{n}=49$ cromoossomos $(7 \mathrm{~m}+18 \mathrm{sm}+14 \mathrm{st}+10 \mathrm{a})$ foi também encontrado e, pelas características apresentadas, pode ser uma conseqüência de um raro evento de hibridização entre os citótipos A e B. As análises morfométricas de variáveis canônicas indicam um isolamento consistente da amostra da Furna 2 enquanto as demais amostras analisadas se apresentam sobrepostas indicando um possível fluxo gênico ou evento de isolamento recente. Este modelo aponta para um complexo de espécies crípticas na região estudada.

Key words: Tetra, Morphometrics, Karyotype, Sympatry, Cryptic species.

\section{Introduction}

The freshwater ichthyofauna of the Neotropical region is the most diverse of the world, being estimated in more than 8,000 species (Schaefer, 1998). The rio Paraná basin, composed of the rio Paraná, rio Paraguay and rio Uruguay and their affluents, is one of the richest basins in South America in terms of fish species, with more than 550 already described (Britski, 1972). The rio Tibagi, object of the present study, is an affluent of the left bank of the rio Paranapanema which, in turn, discharges in the Paraná river in its upper course, above the Sete Quedas region, belonging, therefore, to the upper Paraná system (Medri et al., 2002).

In Astyanax, morphological, cytogenetical and genetic-

*Universidade Estadual de Ponta Grossa, Campus de Uvaranas, Departamento de Biologia Estrutural, Molecular e Genética, 84030-900 Ponta Grossa, PR, Brazil. e-mail: rfartoni@uepg.br

**Universidade Estadual de Londrina, Museu de Zoologia, Caixa Postal 6001, 86051-990 Londrina, PR, Brazil.

***Universidade Federal de São Carlos, Programa de Pós-Graduação em Genética e Evolução, Caixa Postal 676, 13565-905 São Carlos, SP, Brazil. 

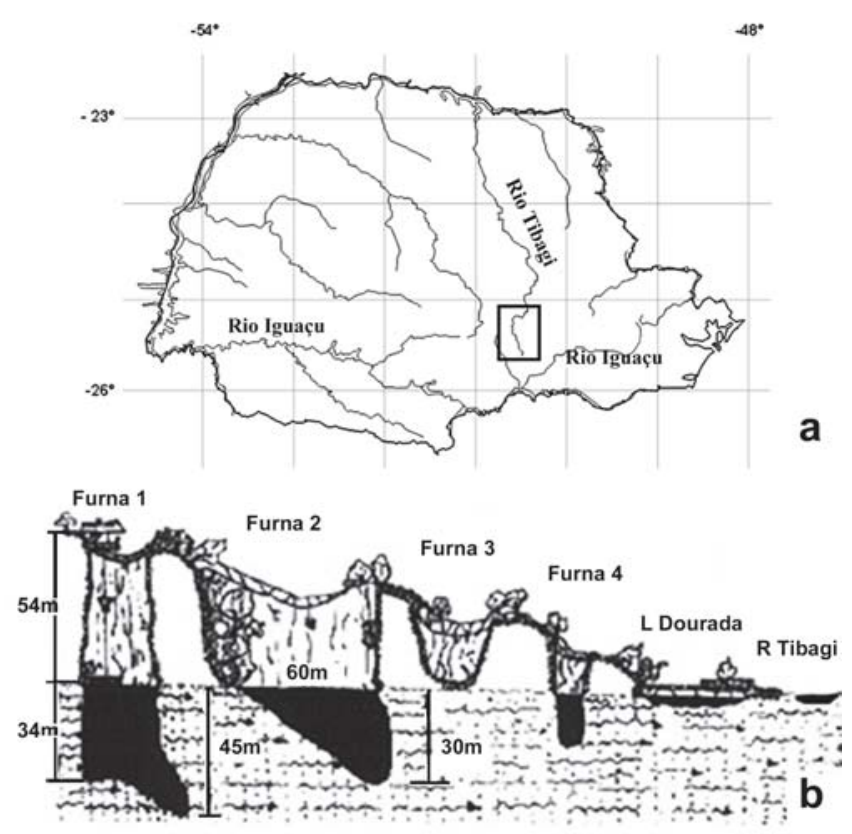

Fig. 1. Collecting sites of Astyanax aff. fasciatus in the upper rio Tibagi region, Paraná, Brazil (a). Geological profile of the Furnas and Lagoa Dourada in relation to the rio Tibagi (b).

biochemical studies have demonstrated that populations of many nominal species are differentiated, as is seen in Astyanax scabripinnis (Caramaschi, 1986; Moreira-Filho \& Bertollo, 1991; Maistro et al., 1998; Munim et al., 2004) and Astyanax fasciatus (Justi, 1993; Centofante et al., 2003).

The present work analyzes Astyanax aff. fasciatus samples occurring in the region of the upper rio Tibagi and its affluents in regards to karyotypic evolution. Different karyotypic forms that may be found in a sympatric condition were detected.

\section{Material and Methods}

One hundred and thirteen specimens (27 males and 86 females) of Astyanax aff. fasciatus Cuvier, 1819, captured between the years 2000 and 2003 in the region of influence of the upper rio Tibagi, in the proximities of the Ponta Grossa municipal district (Paraná State, Brazil), were studied (Fig. 1a). All specimens are currently deposited in the ichthyological collection of the Zoology Museum of the Universidade Estadual de Londrina (Paraná, Brazil) (vouchers numbers MZUEL 1792, 1794, 1795, 3735). A total of four samples from Furna 2 and Lagoa Dourada (in the Vila Velha State Park) and from the rio Tibagi and rio Cará-cará were studied. All 113 specimens were submitted to karyotypic analyses, and 63 were submitted to morphometric analyses.

Chromosomal preparations were obtained by the "air drying" method (Bertollo et al., 1978). Constitutive heterochromatin was detected according to Sumner (1972). The chromosomes were organized in metacentric (m), submetacentric (sm), subtelocentric (st) and acrocentric (a) in a decreasing order

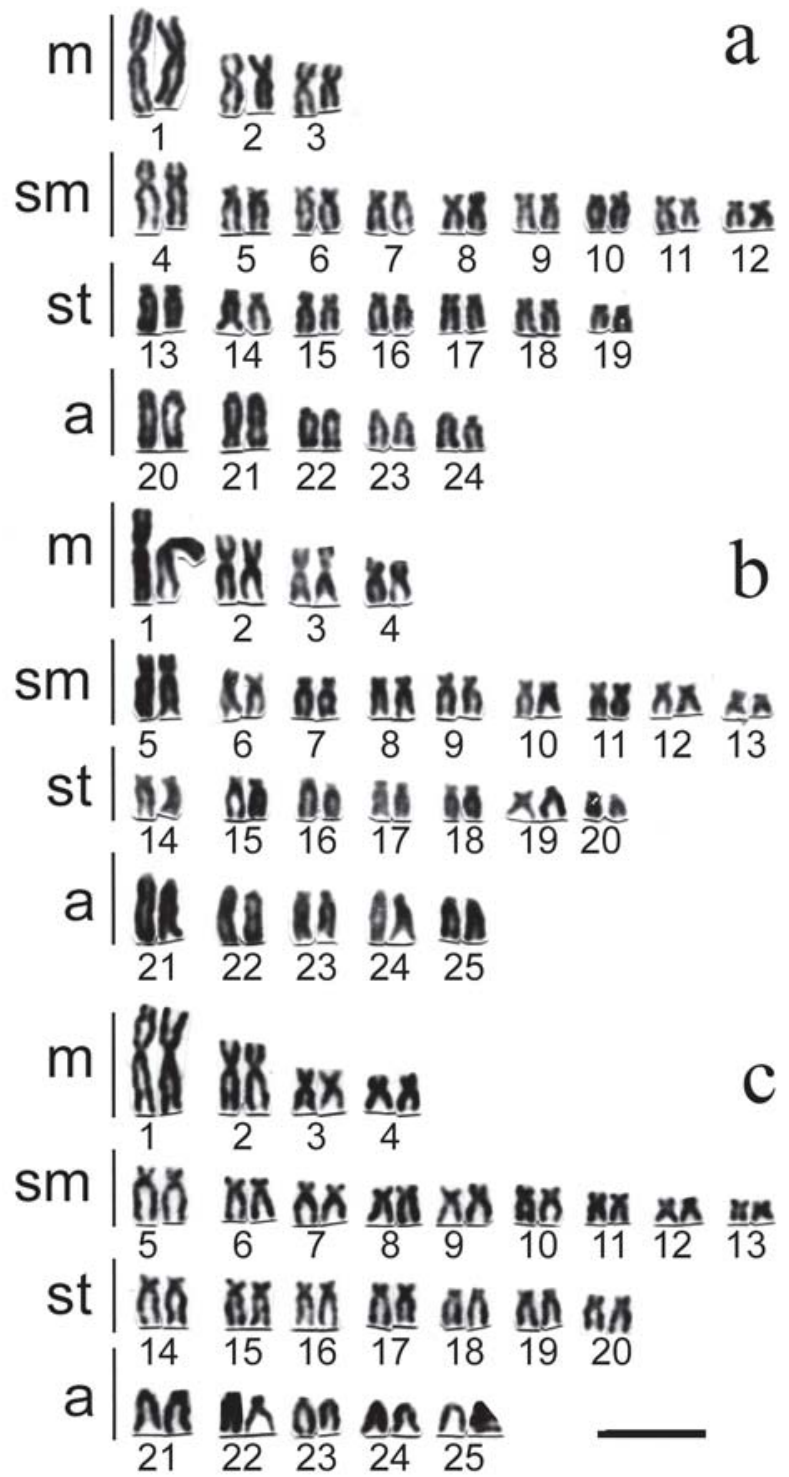

Fig. 2. Conventional karyotypes found in Astyanax aff. fasciatus of the upper rio Tibagi region (Ponta Grossa, Paraná State, Brazil). In (a), cytotype A ( $2 \mathrm{n}=48$ chromosomes), in (b) cytotype $\mathrm{B}(2 \mathrm{n}=50$ chromosomes) and in (c) cytotype $\mathrm{C}(2 \mathrm{n}=50$ chromosomes). Bar: $5 \mu \mathrm{m}$.

of size, according to arm ratios (Levan et al., 1964).

For the morphometric analyses, point-to-point measures of standard length, head length, pre-dorsal distance, dorsal fin base length, pre-ventral distance, anal-fin base length, body depth, caudal peduncle depth, eye diameter, interorbital distance and snout length were performed with a digital caliper of $0.01 \mathrm{~mm}$ precision. Twenty specimens from Furna 2, 14 from Lagoa Dourada, 14 from the rio Cará-cará and 15 from the rio Tibagi were measured. For the size-free canonical variate analysis, the statistical package PAST v. 1.35 (Hammer et al., 2001) was employed, using the "normalize size 2D" and "Log" data transformation and the "Multivar MANOVA/ CVA" command. 


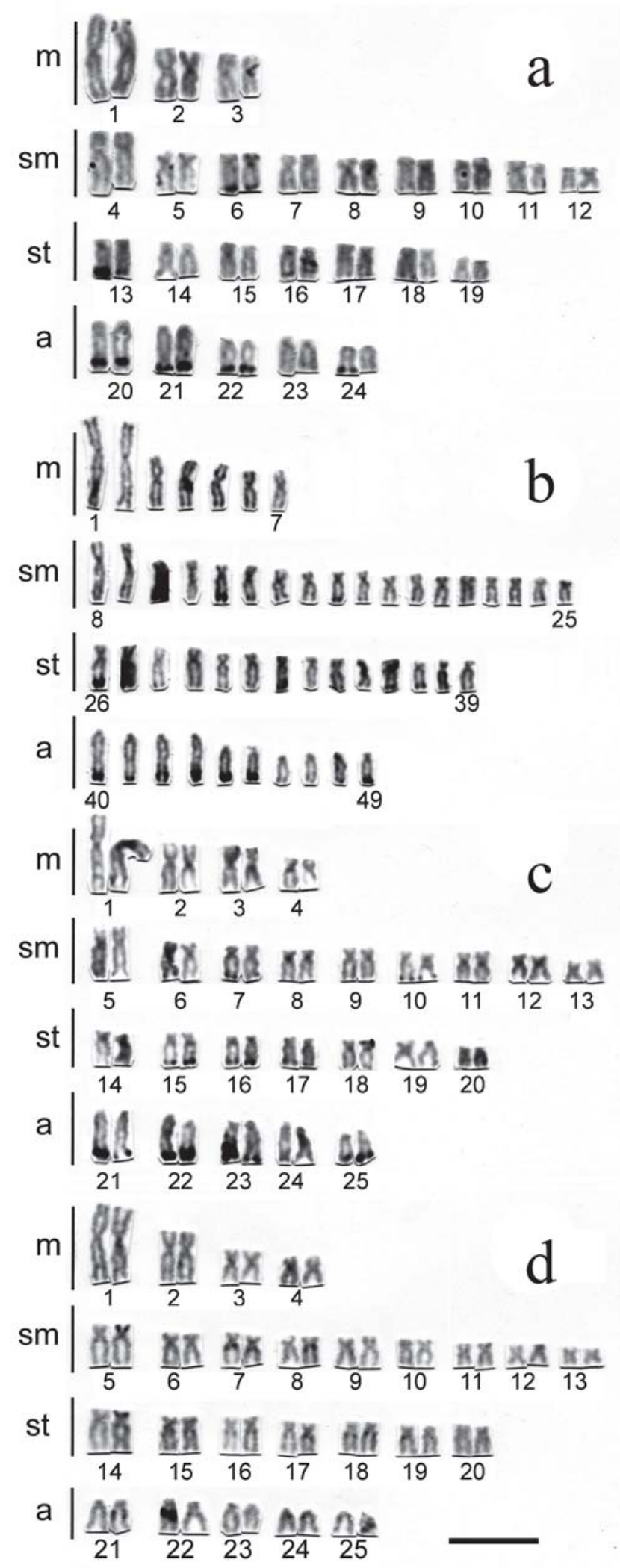

Fig. 3. C-banding karyotypes found in Astyanax aff. fasciatus of the upper rio Tibagi region (Ponta Grossa, Paraná State, Brazil). In (a), cytotype A $(2 n=48)$, in (b) karyotype of the specimen with $2 n=49$ chromosomes, presenting a C-banding pattern similar to cytotypes $A$ and $B$, in (c) cytotype $B(2 n=50)$ and in (d) cytotype $C(2 n=50)$. Bar: $5 \mu \mathrm{m}$.

\section{Results}

In general, three distinct basic karyotypes (cytotypes) were identified among the $113 \mathrm{~A}$. aff. fasciatus specimens, here denominated cytotypes A, B and C (Table 1). In all cases, no significant differences were detected between male and female karyotypes, thus no morphologically differentiated sex chromosomes were identified. Cytotype A is characterized for presenting $2 \mathrm{n}=48$ chromosomes, 6 being metacentric, 18 submetacebtric, 14 subtelocentric and 10 acrocentric. Cytotypes B and C present the same diploid number, $2 \mathrm{n}=50$ chromosomes, as well as identical karyotypic formulas composed of 8 metacentric, 18 submetacentric, 14 subtelocentric and 10 acrocentric chromosomes (Fig. 2). However, considering their constitutive heterochromatin pattern posteriorly described, these two cytotypes are mutually differentiated and also differentiated in the size of their first acrocentric chromosome pairs, clearly larger in cytotype B. Sympatry was observed between distinct cytotypes in the upper rio Tibagi region with the exception of the Furna 2 sample that presents cytotype A exclusively (Table 1).

In cytotypes $\mathrm{A}$ and $\mathrm{B}$, the heterochromatin was mainly distributed as very conspicuous blocks in the telomeric region of the long arms of acrocentric chromosomes. Nevertheless, few chromosomes bears heterochromatin in cytotype $\mathrm{C}$, and they are almost always interstitially located (Fig. 3).

Besides these three distinct karyotypic forms, the occurrence of a specimen from the rio Cará-cará exhibiting $2 n=49$ chromosomes with 7 being metacentric, 18 submetacentric, 14 submetacentric and 10 acrocentric was also verified, with a distribution pattern of constitutive heterochromatin identical to that observed in cytotypes A and B (Fig. 3).

With the canonical variate analysis of the combined samples, 3 axes were obtained in which the first two represent $96.05 \%$ of the variation of the original matrix ( $84.6 \%$ for axis 1 and $11.45 \%$ for axis 2 ). The Wilk's lambda test evidences that these axes are significantly and mutually different $(\ddot{e}=0.0346$, $\left.\mathrm{F}=8.421, \mathrm{p}=2.187 \times 10^{-19}\right)$. Two groups were distinguishable in the first axis (Fig. 4). The Furna 2 sample was discriminated from the others because it presented the greatest head length and eye diameter, while the caudal peduncle depth, body depth and pre-dorsal distance were larger in the other three samples (Table 2). In the second axis, the rio Tibagi sample presented a tendency to discriminate from the rio Cará-cará and Lagoa Dourada samples, although three specimens were superimposed to the specimens of these two samples. The variables that presented the greatest values for the rio Tibagi sample were pre-ventral distance, snout length, head depth, interorbital distance and standard length. The Cará-cará river sample could not be morphometrically differentiated from that of Lagoa Dourada.

\section{Discussion}

Chromosomal evidences indicate that Astyanax fasciatus seems to constitute a species complex (Justi, 1993; Centofante 
Table 1. Karyotypic characteristics of the populational samples of Astyanax aff. fasciatus from Furna 2, rio Tibagi, Lagoa Dourada and rio Cara-cará. $2 \mathrm{~N}$ = diploid chromossomal number; $\mathrm{NF}=$ fundamental number; sex: $\mathrm{f}=$ female, $\mathrm{m}$ = male; karyotype: $\mathrm{m}=$ metacentric; $\mathrm{sm}=$ submetacentric; $\mathrm{st}=$ subtelocentric; $\mathrm{a}=$ acrocentic; cytotype: $\mathrm{X}=$ probable hybrid form. References (Ref.): (1) Matoso et al. (2002); (2) Gross et al. (2004); (3) Present study.

\begin{tabular}{lcccccc}
\hline Locality & Sample/ Sex & 2N & NF & Karyotype & Cytotype & Ref. \\
\hline Furna 1 & $5 \mathrm{f} / 5 \mathrm{~m}$ & 48 & 72 & $6 \mathrm{~m}+18 \mathrm{sm}+14 \mathrm{st}+10 \mathrm{a}$ & $\mathrm{A}$ & 1 \\
Furna 2 & $25 \mathrm{f} / 10 \mathrm{~m}$ & 48 & 72 & $6 \mathrm{~m}+18 \mathrm{sm}+14 \mathrm{st}+10 \mathrm{a}$ & $\mathrm{A}$ & $2 ; 3$ \\
Rio Tibagi & $1 \mathrm{f}$ & 48 & 72 & $6 \mathrm{~m}+18 \mathrm{sm}+14 \mathrm{st}+10 \mathrm{a}$ & $\mathrm{A}$ & 3 \\
Rio Tibagi & $23 \mathrm{f} / 4 \mathrm{~m}$ & 50 & 76 & $8 \mathrm{~m}+18 \mathrm{sm}+14 \mathrm{st}+10 \mathrm{a}$ & $\mathrm{B} / \mathrm{C}$ & 3 \\
Lagoa Dourada & $8 \mathrm{f} / 1 \mathrm{~m}$ & 48 & 72 & $6 \mathrm{~m}+18 \mathrm{sm}+14 \mathrm{st}+10 \mathrm{a}$ & $\mathrm{A}$ & 3 \\
Lagoa Dourada & $9 \mathrm{f} / 3 \mathrm{~m}$ & 50 & 76 & $8 \mathrm{~m}+18 \mathrm{sm}+14 \mathrm{st}+10 \mathrm{a}$ & $\mathrm{B} / \mathrm{C}$ & 3 \\
Rio Cará-cará & $15 \mathrm{f} / 8 \mathrm{~m}$ & 48 & 72 & $6 \mathrm{~m}+18 \mathrm{sm}+14 \mathrm{st}+10 \mathrm{a}$ & $\mathrm{A}$ & 3 \\
Rio Cará-cará & $1 \mathrm{~m}$ & 49 & 74 & $7 \mathrm{~m}+18 \mathrm{sm}+14 \mathrm{st}+10 \mathrm{a}$ & $\mathrm{X}$ & 3 \\
Rio Cará-cará & $5 \mathrm{f}$ & 50 & 76 & $8 \mathrm{~m}+18 \mathrm{sm}+14 \mathrm{st}+10 \mathrm{a}$ & $\mathrm{B}$ & 3 \\
\hline
\end{tabular}

et al., 2003), as is also observed in Astyanax scabripinnis (Moreira-Filho \& Bertollo, 1991), despite very distinct ecological characteristics. In its turn, morphological analyses also reinforce the occurrence of a "fasciatus" complex (Garutti \& Britski, 2000). The data of the present study also serve to corroborate this proposition. The high dispersion capacity added to the geographical isolation must represent conditions of extreme importance for the diversity that has been reported for this group. In fact, Astyanax is widely distributed throughout South America (Gèry, 1977) and inhabit lotic and lentic environments or are even restricted to the headwaters of streams inhospitable for other fish.

The Furnas of the Vila Velha State Park in Paraná State (Fig. 1b) are collapse wells formed in the Pleistocene with water levels reaching the groundwater and with no direct communication between them or with other bodies of water, allowing them to be considered as regions of endemism for Astyanax (Artoni \& Almeida, 2001). The morphological evidences emphasized by canonical variates analysis indicate that the Furna 2 population is in fact differentiated from the other populations here studied, probably due to an absence of gene flow.

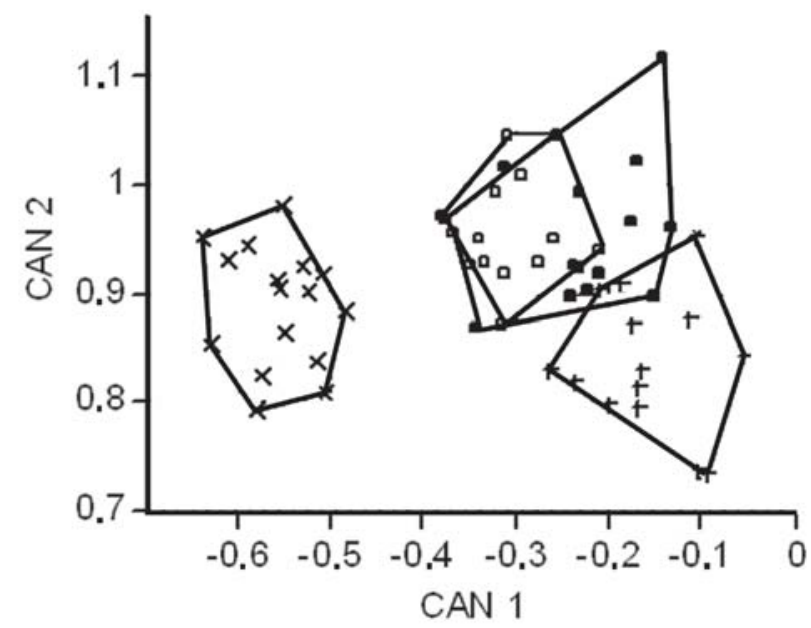

Fig. 4. Distribution of the individual scores of the size-free canonical variate combining the samples from the Vila Velha State Park localities (Furna 2) (x), rio Tibagi (+), Lagoa Dourada (light square) and rio Cará-cará (shaded square).
The Astyanax aff. fasciatus karyotype at Furna 2, previously described by Gross et al. (2004), was reanalyzed and its karyotypic structure confirmed, corresponding to cytotype A. In truth, according to previous studies of Matoso et al. (2002), this cytotype also characterizes the Astyanax aff. fasciatus sample at Furna 1. The karyotypic macrostructure of cytotype A is similar to those observed in different samples of the "scabripinnis complex" and in A. fasciatus samples with a diploid number of $2 n=48$ chromosomes, with a preferential distribution of the constitutive heterochromatin in the acrocentric chromosomes (Figs. 3a, b and c).

On the other hand, when the karyotypic data of other Astyanax aff. fasciatus samples (cited in Artoni \& Almeida, 2001 and Matoso et al., 2002 as Astyanax sp.) were compared, we verified the presence of two other distinct cytotypes (B and C) that may occur in sympatry (Figs. 2-3; Table 1). Despite the difference of diploid number, cytotypes A and B evidence a very similar karyotypic macrostructure and C-banding pattern, with conspicuous heterochromatic blocks in the extremity of the long arm of acrocentric chromosomes (Fig. $3 \mathrm{a}, \mathrm{c})$. On the other hand, in spite of presenting the same diploid number as cytotype $\mathrm{B}$, cytotype $\mathrm{C}$ has a very distinct constitutive heterochromatin distribution pattern, with few conspicuous bands almost always interstitially located in the long arm of submeta-, subtelo- and acrocentric chromosomes

Table 2. Weight of the variables in the first two axes of the size-free canonical variate analysis (CAN1 and CAN2) of the combined Astyanax aff. fasciatus samples from Furna 2, rio Tibagi, lagoa Dourada and rio Cara-cará.

\begin{tabular}{lcc}
\hline Measures & CAN 1 & CAN 2 \\
\hline Standard length & -0.039029 & -0.2452 \\
Head length & -0.24178 & -0.063553 \\
Pre-dorsal distance & 0.22351 & -0.29036 \\
Dorsal fin base length & 0.08114 & -0.059463 \\
Pre-ventral distance & -0.035194 & -0.48002 \\
Anal-fin base length & -0.029941 & 0.36196 \\
Body depth & 0.50892 & -0.35115 \\
Caudal peduncle depth & 0.57028 & 0.39155 \\
Eye diameter & -0.54403 & -0.00013771 \\
Interorbital distance & -0.0162 & -0.289 \\
Snout length & 0.029858 & -0.35555 \\
Eigenvalue & 8.563 & 1.159 \\
\% & 84.6 & 11.45 \\
\hline
\end{tabular}


(Fig. 3d). It is worth pointing out that the specimen from rio Cará-cará with $2 \mathrm{n}=49$ chromosomes has a basic karyotypic structure and a constitutive heterochromatin distribution pattern similar to those of cytotypes A and B (Fig. 3b), therefore representing a possible rare hybridization event between these cytotypes, or less probably a case of extra chromosomes (B-chromosomes), as already seen in a few Astyanax species (Moreira-Filho et al., 2001).

In Astyanax scabripinnis, Souza \& Moreira-Filho (1995) and Maistro et al. (2000) also verified the occurrence of sympatric cytotypes, not dismissing the possibility that this condition is the consequence of a secondary contact of originally allopatric populations. These observations, together with the data obtained in the present study, restates the complex karyotypic structure that has been seen in different Astyanax samples. Matoso et al. (2004), using RAPD-PCR molecular markers in Astyanax aff. fasciatus (cited as Astyanax sp.), evidenced the same population structuring verified by the present morphological and karyotypic analysis, reinforcing the hypothesis that this panorama is as indicator of the presence of a cryptic species complex in the upper rio Tibagi basin.

Whether in species with more restricted habits, such as A. scabripinnis that is confined to the headwaters of streams, or in species with a broader vagility, such as $A$. fasciatus, the karyotypic diversity must occur in consequence of the fixation of chromosomal rearrangements in the populations, influenced by factors like effective population size, gene flow and/or genetic drift. However, the importance of historical processes that led to allopatric speciation as well as current sympatry zones must also be highlighted, bearing in mind the low frequency of detected hybrids in contrast with the cytotypes invariably well-fixed in the populations analyzed in regards to this aspect until now.

\section{Acknowledgements}

We thanks to Instituto Ambiental do Paraná, Instituto Brasileiro do Meio Ambiente e Recursos Naturais Renováveis for licence of fish capture, and to $2^{\circ} \mathrm{GB}$ (Ponta Grossa Firemen) for support in fish collections, and to Fundação Araucária de Apoio ao Desenvolvimento Científico e Tecnológico do Estado do Paraná and Conselho Nacional de Desenvolvimento Científico e Tecnológico for financial supports.

\section{Literature Cited}

Artoni, R. F. \& M. C. Almeida. 2001. A singular diversidade dos peixes dos Campos Gerais: uma visão genética para abordagem conservacionista da região. Pp. 505-518. In: Ditzel, C. H. M. \& C. L. L. Sahr. (Org.). Espaço e Cultura: Ponta Grossa e os Campos Gerais. Ponta Grossa, Editora UEPG, 518 p.

Bertollo, L. A. C., C. S. Takahashi \& O. Moreira-Filho. 1978. Cytotaxonomic considerations on Hoplias lacerdae (Pisces, Erythrinidae). Brazilian Journal of Genetics, 1: 103-120.
Britski, H. A. 1972. Peixes de água doce do Estado de São Paulo: Sistemática. Pp. 79-108. In: S. M. Branco (Org.). Poluição e Piscicultura. São Paulo, Brasil: Faculdade de Saúde Pública da USP e Instituto de Pesca. São Paulo, 216 p.

Caramaschi, E. P. 1986. Distribuição da ictiofauna de riachos das bacias do Tietê e do Paranapanema, junto ao divisor de águas (Botucatu, SP). Unpublished Ph. D. Thesis. Universidade Federal de São Carlos, São Carlos. 245 p.

Centofante, L., L. A. C. Bertollo, P. A. Buckup \& O. Moreira-Filho. 2003. Chromosomal divergence and maintenance of sympatric Characidium fish species (Crenuchidae, Characidiinae). Hereditas, 138(3): 213-218.

Garutti, V. \& H. A. Britski. 2000. Descrição de uma espécie nova de Astyanax (Teleostei: Characidae) da bacia do Alto Rio Paraná e considerações sobre as demais espécies do gênero na bacia. Comunicações do Museu de Ciências e Tecnologia da PUCRS, Ser. Zool., 13: 65-88.

Géry, J. 1977. Characoids of the World. Neptune City, NJ, T.F.H. Publications, 672p.

Gross, M. C., C. H. Schneider, M. C. Almeida, M. L. Leite, L. A. C. Bertollo \& R.F. Artoni. 2004. Population structure, fluctuating asymmetry and genetic variability in an endemic and highly isolated Astyanax sp. fish population (Characidae). Genetics and Molecular Biology, 27: 529-535.

Hammer, Ø., D.A.T. Harper \& P. D. Ryan. 2001. PAST: Paleontological Statistics Software Package for Education and Data Analysis. Palaeontologia Electronica, 4(1): 9pp.

Justi, A. J. 1993. Caracterização cariotípica de populações de Astyanax fasciatus (Cuvier, 1819) Pisces, Characidae, em três bacias hidrográficas. Unpublished Master's Thesis. Universidade Federal de São Carlos, São Carlos. 83p.

Levan, A., K. Fredga \& A. A. Sandberg. 1964. Nomenclature for centromeric position on chromosomes. Hereditas, 52: 201-220.

Maistro, E. L., C. Oliveira \& F. Foresti. 1998. Comparative cytogenetic and morphological analysis of Astyanax scabripinnis paranae (Pisces, Characidae, Tetragonopterinae). Genetics and Molecular Biology, 21: 201-206.

Maistro, E. L., C. Oliveira \& F. Foresti. 2000. Sympatric occurrence of two cytotypes of Astyanax scabripinnis (Characiformes, Characidae). Genetics and Molecular Biology, 23: 365-369.

Matoso, D. A., R. F. Artoni \& P. M. Galetti Jr. 2004. Genetic diversity of the small characid fish Astyanax sp., and its significance for conservation. Hydrobiologia, 527: 223-225.

Matoso, D. A., M. R. Vicari, M. C. Almeida, O. A. Shibatta, O. Moreira-Filho, L. A. C. Bertollo \& R. F. Artoni. 2002. Karyotypic studies in the Characidae fish, genus Astyanax. An endemic and highly isolated population of Astyanax sp. Cytologia, 67: 123-128.

Medri, M. E., E. Bianchini, O. A. Shibatta \& J. A. Pimenta. 2002. A bacia do Rio Tibagi. Londrina, 595p.

Moreira-Filho, O., A. S. Fenocchio, M. C. Pastori \& L. A. C. Bertollo. 2001. Occurrence of a metacentric macrochromosome B in different species of the genus Astyanax (Pisces, Characidae, Tetragonopterinae). Cytologia, 66: 59-64.

Moreira-Filho, O.\& L. A. C. Bertollo. 1991. Astyanax scabripinnis (Pisces, Characidae): a species complex. Brazilian Journal of Genetics, 14: 331-357.

Munin, F. S., M. L. Schwantes \& A. R. Schwantes. 2004. NADPdependent isocitrate dehydrogenase of Astyanax scabripinnis (Pisces, Characidae) from three altitudes at Grande stream, Campos do Jordão, SP. Brazil. Brazilian Journal of Biology, 64(2): 273-284. 
Schaefer, S. A. 1998. Conflict and resolution: Impact of new taxa on phylogenetic studies of the neotropical cascudinhos (Siluroidei: Loricariidae). Pp. 375-400. In: Malabarba, L. R., R. E. Reis, R. P. Vari, Z. M. S. Lucena \& C. A. S. Lucena. (Eds.). Phylogeny and classification of neotropical fishes. Porto Alegre, Edipucrs, $603 p$.

Souza, I. L. \& O. Moreira-Filho. 1995. Cytogenetic diversity in the Astyanax scabripinnis (Pisces, Characidae) complex. II. Different cytotypes living in sympatry. Cytologia, 60: 273-281.
Sumner, A. T. 1972. A simple technique for demonstrating centromeric heterochromatin. Experimental Cell Research, 75:304-306

Received November 2005 Accepted April 2006 